Article

\title{
Communication Strategies in Social Media in the Example of ICT Companies
}

\author{
Anna Losa-Jonczyk \\ Department of Communication Design and Analysis, University of Economics in Katowice, \\ 40-287 Katowice, Poland; anna.losa-jonczyk@ue.katowice.pl
}

Received: 17 March 2020; Accepted: 2 May 2020; Published: 5 May 2020

check for updates

\begin{abstract}
This article aims to present the results of pilot studies on the involvement of the four largest Information Communication Technology (ICT) companies in promoting the Sustainable Development Goals (SDGs) through social media. Studies examine which communication strategy is used by companies in social media. The research was carried out using the method of the content of messages posted on the official Facebook and Twitter accounts of the ICT companies' analysis. The analysis showed that the companies prefer corporate ability communication strategy over Corporate Social Responsibility (CSR) or a hybrid one. Posts rarely concern the company's activities related to social and environmental responsibility. Although they engage in activities supporting the achievement of the SDGs and provide information about it on their corporate websites, the topic of sustainable development has been taken up in small numbers in the posts examined.
\end{abstract}

Keywords: communication; social media; strategy; sustainable development; corporate responsibility; ICT industry

\section{Introduction}

Nowadays, a responsible business is a business that joins in the achievement of the Sustainable Development Goals (SDGs), which were declared by the United Nations in 2015 and are binding for all nations. Enterprises that have a significant impact on society and environment should play a key role in promoting and implementing the SDGs. Increasing amounts of transmitted data in mobile networks, the maintenance of server rooms, data centers and the production of new equipment increase the share of Information Communication Technology (ICT) companies' global greenhouse gas emissions. Furthermore, products and services offered by enterprises in this industry significantly affect changes in the functioning of individuals and societies, that's why this industry should be the subject of research.

The article aims to present the results of pilot studies on the involvement of the four largest ICT companies in promoting the Sustainable Development Goals through social media. Studies examine which communication strategy—corporate ability or corporate social responsibility—is used by companies in social media.

In the first part of the article, Sustainable Development and Corporate Social Responsibility are described. Then in the second part, the methodology of the research is presented, followed by the results of the study and discussion. The last part of the article presents conclusions and research limitations.

\section{Literature Review}

\subsection{Sustainable Development}

In September 2015, the United Nations member states adopted the document Transforming our world-An Agenda for Sustainable Development 2030 [1], which includes 17 Sustainable Development Goals [2]. The implementation of the adopted directions of development is to eliminate poverty, 
reduce inequalities and preserve or improve the state of the natural environment while ensuring economic growth worldwide.

The Sustainable Development Goals (SDGs), adopted by 193 countries, are a broad vision of a better future for the world but firmly rooted in reality. For each goal, tasks have been set with specific indicators to be achieved by the end of 2030. In order to achieve it, joint actions of governments of all countries are needed, which will make real changes in politics and the economy. However, the business also plays a crucial role in achieving the goals, which is why the United Nations has called on the private sector to engage in activities aimed at global sustainable development. The business has great potential to support the achievement of the SDGs in many areas. Starting with The Goal 8, promoting decent work for all people and economic growth, where private companies have a wide range of activities to address labor issues, through the goal of the right to equal treatment of the sexes (Goal 5) and the creation of multilateral partnerships for sustainable development (Goal 17). The role of business in achieving environmental objectives is also invaluable (Goals 6, 7, 13, 14, 15 and 16). One of the key arguments supporting the thesis about the obligation for a business to join the fight for environmental improvement is the fact that it is a business that contributes most to its devastation.

Companies can contribute to the implementation of the SDGs in two ways. Firstly, by educating the society and promoting the idea of sustainable development and the SDGs. Implementation of educational activities and running information and promotion campaigns seems to be the easiest way to get involved in the activities for Agenda 2030.

Greater business involvement is required to integrate the SDGs into the company's development strategy and to implement specific actions at the operational level. However, surveys conducted annually by The Ethical Corporation show that the interest of business in incorporating the SDGs into their daily business activities is growing [3]. Aware of the considerable role that business plays in the implementation of Sustainable Development, the UN Global Compact, in parallel with the development of the SDGs, has also undertaken work on cooperation programs with the private sector. The programs' recommendations also refer to the ICT industry, as these companies have a significant impact on society but also have great opportunities to contribute to the achievement of the SDGs.

The ICT sector is currently the main driver of development and innovation worldwide. Modern, advanced information and communication technologies significantly affect the competitiveness of enterprises and national economies, as well as changes in the functioning of modern societies [4]. When analyzing the impact of the ICT sector on the economy and society, one cannot forget about the adverse effects of its activities. The main factors influencing environmental pollution by enterprises in this sector are considered to be materials used in the production of ICT equipment (harmful chemicals) and energy consumed during the manufacture of products and later in the process of their use [5]. The results of an analysis conducted by McMaster University [6] showed that the carbon footprint left by IT equipment in 2007 accounted for 1 percent of the carbon footprint and the forecast of the carbon footprint of ICTs for 2040 is 14 percent of total greenhouse gas emissions.

The amount of $\mathrm{CO} 2$ emitted during the production of a new smartphone equals the amount of gas emitted to the atmosphere when using an existing smartphone model within ten years. Large companies are still tempting consumers with new models of their products, which causes another environmental problem-disposal of used equipment. The increasing number of transmitted data, maintenance of server rooms and data centers further increase the share of the ICT industry in global greenhouse gas emissions. The environmental impact of ICT companies is significant, so reducing the negative impact of the industry remains one of its priorities. ICT companies are the primary energy consumer in urban areas and the European Union is promoting measures to improve the energy efficiency of the sector in order to reduce gas emissions. The actions can be divided into two groups-the first one is actions to greening the ICT sector and the second one is the ecology-enhancing actions that the ICST supports. The database of good practices of enterprises in an area of greening information technologies has been developed as part of the Green IT Network Europe Project [7]. Not only in the pro-environmental area, the ICT sector is obliged to take corrective actions but equally, often issues of ensuring appropriate 
working conditions in the supply chain are raised (e.g., in companies involved in the extraction of needed raw materials, production of electronic components or recycling of used electronics).

Stakeholders' expectations of ICT companies apply to both the activities of companies and using the communication opportunities offered by their products and services. The developing communication technologies make it possible not only to reach a vast audience with information on Sustainable Development but also to involve the recipients of communications in the debate on Sustain Development and actual participation in activities supporting the implementation of SDGs [8].

\subsection{Corporate Social Responsibility}

The contemporary discussion on corporate responsibility (CSR) and sustainable development shows a clear analogy between the two concepts [9]. Sustainable development means development that meets people's current needs without compromising future generations' ability to meet their needs. In order to achieve the SDGs, it is necessary to have three elements-economic growth, social inclusion and environmental protection [10]. This is a type of development that, using appropriate technologies, does not degrade the environment, is economically viable and socially acceptable. In the early definitions of CSR appearing in the literature, ecological aspects were rarely emphasized. A. Dashlrud explains this fact by the division of CSR at the end of the 20th century by the World Business Council for Sustainable Development into two areas-corporate social responsibility and corporate environmental responsibility [11]. However, both environmental, social and economic areas are marked in the definition contained in 2010 in ISO 26000 standard. The definition states that an organization's social responsibility is a responsibility for the impact of its decisions and actions (products, services, processes) on society and the environment through transparent and ethical behavior that contributes to sustainable development, health and well-being of society [12]. The standard assumptions of CSR and Sustainable Development make these concepts often used interchangeably [13].

The changes taking place both in the field of information and communication technologies used in organizations, as well as in the awareness of a wide range of stakeholders, expecting from an organization the transparency of activities and real dialogue, have increased the importance of CSR and Sustainable Development communication among company managers and scientists. The first attempt to separate research on corporate social responsibility communication in the research area of the phenomenon of CSR based on scientific discussion took place in 2002. Maignan and Ralston published the results of research on CSR communication online, which was conducted in Europe and the United States. For the first time, the authors marked the distinction between social responsibility practices and CSR communication [14,15].

A retrospective look at the development of interest of researchers and practitioners in communicating CSR allows for distinguishing several stages of the perception's evolution of this issue and factors that influenced the changes in the perception of communicating social responsibility [16]. Specific periods of evolution, together with factors of change, are presented in Table 1.

Table 1. External factors determining changes in the approach to communicating Corporate Social Responsibility (CSR).

\begin{tabular}{ccc}
\hline Factor & Period & Changes in the CSR Communicating \\
\hline $\begin{array}{c}\text { Stakeholder involvement and co-creation } \\
\begin{array}{c}\text { Stakeholder transparency requirements, } \\
\text { the growing role of social media }\end{array}\end{array}$ & 2010 -currently & $\begin{array}{c}\text { From linear to networked CSR } \\
\text { communicating }\end{array}$ \\
\hline $\begin{array}{c}\text { Stimulation of governmental and } \\
\text { no-governmental organizations }\end{array}$ & The 1990s-2000 & $\begin{array}{c}\text { The convergence of current CSR and } \\
\text { communication practices }\end{array}$ \\
\hline Increased activity in CSR & The 1990s. & CSR reporting \\
\hline Source: Own study based on Golob et al. [16].
\end{tabular}

\footnotetext{
Source: Own study based on Golob et al. [16].
} 
The first stage began in the 1990s when business ethics and the practice of combining joint activities of large companies with Non-Governmental Organizations (NGOs) and trade unions became particularly important. The first international initiatives related to the regulation of business ethics principles have emerged, such as the Ethical Trading Initiative or The United Nations Global Compact. During this period, research work, which dealt with aspects of communicating social responsibility, was mainly related to the concept of reputation and management of relations with stakeholders $[17,18]$. The Internet and the opportunities it offered had an increasing influence on changes in communication at that time [15]. The period between the nineties and the beginning of the 21st century was a time of development of governmental and international organizations that supported voluntary CSR activities of business organizations and first attempts at non-financial reporting. The first non-financial report was published by Shell in 1998, thus setting a precedent for other companies [19]. Initiatives were launched during this period that promoted communication of activities for society and environment, developed principles of social reporting and influenced the evolvement of the concept of corporate responsibility and Sustainable Development (e.g., The Global Reporting Initiative or The Organization for Economic Co-operation and Development). The guidelines for non-financial reporting included in the Global Reporting Initiative are still the most frequently used principles in the reporting process undertaken by business and non-business organizations. The initiatives created during that period contributed to increasing the awareness of the need to communicate CSR and Sustainable Development among organizations. After 2008, there are further changes in the perception of CSR communication and the following factors cause them-first of all, there is the institutionalization of non-financial reporting; processes related to reporting of CSR activities take on vital importance in organizations. Moreover, non-financial reporting in some countries ceases to be voluntary and becomes mandatory in certain areas (e.g., France, Germany, Spain, Scandinavia, USA, Japan). In countries where reporting is still optional, pressure from the society, government and foreign contractors makes organizations aware of the need to communicate CSR and Sustainable Development activities to stakeholders using this tool. Companies report on their social and environmental activities because they want to act openly and transparently and show how they contribute to Sustainable Development $[15,20]$.

The process of adapting the communication strategy to the organization's business strategy due to the tendency to treat communication as a strategic business challenge [21] is another factor influencing the change in the perception of social responsibility and Sustainable Development communication. The development of social media resulted in an increase in communication needs on the part of stakeholders requiring the organization to be transparent was also outstanding. After 2011, the time has come when CSR communication has become a subject widely discussed and studied by scientists and practitioners. New tools for communicating with the environment are rapidly appearing and the stakeholders themselves require adjusting the content and channel to their needs. Moreover, stakeholders expect communication, which will be a real dialogue between the organization and its environment. The expansion of social media, in a way, forces the organization's strategic approach to communicating social responsibility and Sustainable Development. Nowadays, the organization's communication has become a tool enabling the participation of stakeholders in the processes of shaping CSR policy and strategy, which respond to real challenges of the internal and external environment [15].

The list of external factors determining changes in the approach to communicating the organization's responsibility is presented in Table 1.

Sustainable Development communication is described in the literature in three forms-corporate communication, advocacy and development communication [22]. Corporate communication in this context refers to the flow of communication within the organization in order to raise employees' level of awareness and competencies about corporate responsibility and the SDGs. Corporate communication is also about creating the image of a responsible organization, aiming at the Sustainable Development, among specific stakeholder groups, for example, local community, supervisory board or customers.

- Advocacy - the purpose of this form of communication is to support the Sustainable Development policy and raise the recipients' awareness of specific problems, such as poverty, the effects of 
climate change or care for clean energy. Advocacy communication goals are achieved primarily through the activities of journalists and widely understood mas media are the tools used in their implementation.

- Development Communication (also referred to as Communication for Development) is defined in the literature as a process of the based on dialog communication, which involves a strategic approach to the use of communication methods and tools to cause social change. It is used to identify and analyze the needs, problems and risks associated with Sustainable Development. The three key elements characteristic of Development Communication are process, dialogue and the pursuit of change.

Mefalopulos and Grenna also analyze in their research the main communication paradigms in the context of Sustainable Development since the last century:

- Modernization paradigm-implemented since the 1950s in communication about global development by emphasizing the role of new technologies and scientific methods in the realization of the idea of maintaining peace and prosperity around the world. Communication took place mainly through mass-media; it was a one-way communication (top-down process).

- The paradigm of dependence-initiated in the 1970s. Communication in this paradigm was understood as a tool for educating society and creating alliances between developing countries. The media should, by definition, be under the supervision of the state, as the state represents the vital interests of society.

- The co-participation paradigm - the third paradigm is based on the idea of public participation in the process of communicating about world development. In this paradigm, the possibility of exchanging opinions, experiences and knowledge between the sender and the recipient is ensured. Society becomes a co-creator of a world development strategy. The adoption of such a model of communicating about Sustainable Development does not change the traditionally understood role of the mass media. The media continue to inform and promote but this is no longer their only function in reality, where every recipient of a message can easily express their opinions.

In the research of the last twenty years, CSR communication has been increasingly important due to its role in the development of CSR policies and activities. The implementation of goals set by socially responsible organizations requires constant adaptation of business and communication strategy to the changing expectations of the environment.

Research shows that communicating using Twitter increases the level of identification of stakeholders, especially consumers, with an organization. According to researchers [23], even though external stakeholders have much less direct contact with an organization than employees, by contacting an organization through social media, stakeholders are often able to build a robust and lasting relationship with it. One of the first research papers trying to explain the role of microblogs in creating relations with the environment, based on the analysis of the content of accounts on Twitter, was the work of M. Etter et al. [24]. By analyzing tweets and reactions to them posted on the accounts of 30 companies, the researchers determined the levels of interactivity and intensity in communicating social responsibility. The intensity level was determined by the quantitative proportion of posts on CSR of the company to posts on other topics. Interactivity was measured by the number of stakeholder responses to published CSR tweets. The analysis resulted in a matrix defining four types of CSR communication strategies that companies can implement using a microblog in the form of Twitter:

1. information strategy that has a low level of interaction regardless of the level of stakeholder response,

2. personalized information strategy where low stakeholder responsiveness is combined with medium to high levels of interactivity,

3. reactive strategy - medium or high level of interactivity is combined with a high level of responsiveness,

4. an engagement strategy, characterized by a medium to a high degree of interactivity with an average level of environmental responsiveness. 
Each of the surveyed companies was assigned to an appropriate strategy and the intensity level of CSR tweets posted by the company was determined. Conclusions from the research were included in the statement that the use of Twitter in communicating social responsibility may contribute to the increase of awareness of the organization's CSR activities. Users make CSR content available to others and reducing the negative attitude of stakeholders towards CSR activities and messages thanks to the dialogue conducted by the company and building relations with the environment. Successive research on the use of the microblog to communicate CSR conducted by Lee et al. [25] and Tao and Wilson [26] has shown that Twitter is an excellent tool to build a communication space for organizations. Those that have conducted CSR activities on a large scale have built a broader community on Twitter's corporate account around their activities than organizations that have not conducted CSR policies. Although Twitter enables organizations to create and conduct a dialogue with their environment, research conducted earlier has proved that organizations still rarely use this tool to communicate CSR. The analysis of company accounts of the surveyed organizations showed higher responsiveness of the organization in communicating CSR and less interactivity than in the case of tweets not concerning social responsibility. The level of organization's interactivity increased only in cases when stakeholders themselves contacted the organization through tweets $[15,27]$.

Also, subsequent studies show that this tool has been used mainly to promote organizations, to a lesser extent, to build dialogue [28]. By investigating how organizations communicate via Twitter, Etter [27] analyzed their communication strategies. Based on the model of communication strategies proposed by Morsing and Schulz [29], the researcher distinguished the following strategies used by organizations in communicating via Twitter accounts:

1. broadcasting strategy - this strategy involves unilateral communication and information is disseminated to an anonymous recipient, rarely to an individual recipient to convey specific information,

2. reactive strategy-allows for two-way communication but messages only appear from the organization when the initiative is created on the side of stakeholders, the organization responds to questions and comments,

3. engagement strategy, enabling a proactive approach by the organization to two-way communication. The organization encourages dialogue, exchange of ideas, asking questions from stakeholders, also by frequently mentioning other users' names in tweets. It is precisely this latter communication strategy, the engagement strategy, that researchers consider being the one that should lead to the highest level of stakeholder identification with the organization and increase consumer loyalty to the brand $[27,30]$.

Sundstrom and Levenshus [31] have narrowed down their applied research on Twitter's social responsibility communication strategies to research media companies. The analysis of the content of messages posted on the microblog allowed to identify three types of communication strategies used by the surveyed companies:

1. strategies for promoting the organization as a leader in the industry,

2. integrating social media by linking to other external sources on the internet (enhancing credibility),

3. creating relationships, fulfilling public relations functions in the context of involving stakeholders in the dialogue.

Research has also been conducted on the use of storytelling elements and emotional expressions in CSR tweets [32]. In the area of communicating CSR through a microblogging service such as Twitter, research was also undertaken in food and brewing companies. The research showed that customers expect companies representing the above industries to communicate about product responsibility; however, none of the surveyed companies used a dialogical, two-way and asymmetrical approach in communicating with the environment via Twitter [33]. Similarly, the results of the Shin and team [34] study showed that companies in most cases, despite using social media and communicating online 
with stakeholders, still treat this channel as a place of one-way communication, mainly for information purposes. As Wigley and Lewis [35] point out, social media is only a communication tool and it is up to the organization to use it. It is the organization's responsibility to provide an environment, both online and offline, with a willingness to listen to what its stakeholders have to say and respond to problems that arise. Therefore, research in the field of social media and social responsibility communication is an important part of the research on the interactivity of communication, which involves all parties of the communication process. Research on the use of official company accounts functioning on Facebook by companies to communicate with their stakeholders was conducted by Kim, Kim and Sung [36], among others. The researchers analyzed company entries on 41 company Facebook accounts and the reactions of stakeholders to these entries, measuring the number of fans, posts posted by stakeholders and the number of responses to company posts. The study examined the correlation between six types of messages sent by a company to its stakeholders via Facebook accounts of the 500 largest companies and the intensity of responses from the recipients of the messages. It verified the research theses on the impact of a given type of message on stakeholder engagement in dialogue with the company [15].

The analysis of the content of posts on company accounts on Facebook, conducted by Haigh et al. [36], showed that organizations communicating social responsibility in social media primarily inform about CSR programs and activities, as well as achievements and awards. The leading communication strategy on Facebook was the strategy of informing about the organization's successes, the quality of products and services, the importance of the organization in the industry (called the corporate ability strategy). The research also proved that conducting interactive communication strengthens the positive perception of the organization and its CSR activities among stakeholders and influences their purchasing decisions [37].

Subsequent research on CSR communication in social media was conducted by Cho, Furey and Mohr [38] concerned with the adopted strategies of CSR communication on Facebook accounts. The analysis of the content of the posts showed that enterprises were more likely to implement an information strategy communicating on social responsibility than an interactive strategy involving stakeholders. The effectiveness of implemented communication strategies turned out to be low; recipients of messages did not engage in dialogue with organizations. Studies on the effectiveness of communicating social responsibility through Facebook accounts were also conducted in empirical studies by Abitbol and Lee [39]. They concluded that the most significant stakeholders' involvement in communication with enterprises was visible in reactions to posts on CSR activities related to the organization's business activity [15].

Research on the effectiveness of CSR communication in social media has so far been carried out in the food, media and brewing industries or cross-sectionally, for example, among Fortune 500 companies. The search of the subject literature made it possible to state that so far, no research has been carried out on communicating the SDGs in social media conducted by companies from the ICT industry.

The communication strategy defines the objectives, content and target groups that the messages formulated by the organization should reach [40]. In the opinion of the researchers, the choice of an appropriate communication strategy is crucial for obtaining a positive attitude of the stakeholders to the organization [41]. The research on communication of an organization's responsibility has revealed several typologies of communication strategies implemented by organizations. The literature most often quotes the typologies introduced by Wagner et al. [42], Drumwright [43], Kim et al. [36], Morsing and Schultz [29], Colleoni [28].

Wagner et al. [42] distinguished-taking into account the frequency of messages sent and financial outlays-two types of social responsibility communication strategies-proactive and reactive. A proactive, more aggressive strategy assumes higher communication-related investments, resulting from a higher frequency of CSR messages, for example, in the form of advertisements. A reactive strategy is characterized by a lower frequency of CSR messages of the organization and significantly lower financial outlays for this type of communication. Some researchers argue that an organization should use a reactive strategy, a unilateral communication strategy to inform stakeholders about its CSR 
activities, explain the motives and sense of the commitment [29]. According to researchers, less frequent communication about CSR brings better results. However, it should also be taken into account that a reactive communication strategy carries the risk of low awareness of CSR activities undertaken by an organization among its stakeholders, which results in a lack of reaction and involvement of stakeholders in the implemented activities. On the other hand, the risk of adopting a proactive strategy is that stakeholders treat communicating social responsibility as "selling" the organization's commitment and creating only the right image [44].

In turn, Drumwright [43] presented the division of CSR communication strategies by purpose and content. He distinguished:

1. strategy of economic communication, where the organization's messages focus on presenting the advantages of products or services,

2. strategy of non-economic communication, the aim of which is to support the image of the organization building good relations with the environment,

3. mixed strategy, which in messages combines the promotion of products and services with the CSR message.

On the typology described above, Kim and others based their research on strategic communication of social responsibility [36]. Researchers also distinguished three main types of communication strategies used by modern organizations, which correspond to the individual strategies presented by Drumwright [43] (corporate ability strategy, corporate social responsibility strategy and hybrid strategy).

The aim of the quality strategy is, as in the economic strategy, to emphasize the quality of products and services and to build the image of the organization as a specialist on the market. Messages sent to stakeholders as part of the adopted strategy often concern the organization's success on the market, sales growth, leadership in the industry. The social responsibility strategy, on the other hand, serves the purpose of conveying information on the activities undertaken by the organization for the benefit of society and the natural environment. A hybrid strategy is a combination of the assumptions of the quality and social responsibility strategy, under which messages are sent to stakeholders concerning both the quality of products and services, as well as socially responsible activities. The aim of the quality strategy is, as in the economic strategy, to emphasize the quality of products and services and to build the image of the organization as a specialist on the market. Messages sent to stakeholders as part of the adopted strategy often concern the organization's success on the market, sales growth, leadership in the industry. The social responsibility strategy, on the other hand, serves the purpose of conveying information on the activities undertaken by the organization for the benefit of society and the natural environment. A hybrid strategy is a combination of the assumptions of the quality and social responsibility strategy, under which messages are sent to stakeholders concerning both the quality of products and services, as well as socially responsible activities [15].

Communication involving two or more parties is a fundamental condition for the implementation of the organization's social responsibility. The level at which organizations engage their stakeholders in the process of communication is a criterion for the division of social responsibility communication strategies in the Morsing and Schultz typology [29]. The researchers defined three types of communication strategies for organizations with their environment:

1. information strategy (unilateral),

2. asymmetrical communication (bilateral),

3. stakeholder involvement (bilateral).

The division, based on the theory of communication with Grunning and Hunt's environment, takes into account the level of stakeholder involvement in communicating and co-creating social responsibility. Individual levels are determined by system variables, such as location in the structure of the decision-making system concerning CSR activities and communication about them, perception by the organization of the role of stakeholders, the structure of key success indicators of the department 
responsible for communication with the environment, the main strategic task of communication and support for CSR activities of the organization by external institutions [15,29,45].

Organizations that implement an information strategy communicate unilaterally, providing their stakeholders with information on CSR policy and activities but not expecting a response to the messages sent. An information strategy assumes that an organization can influence its stakeholders through communication while they are treated as potential opposition or support for the organization's actions and decisions. The main task of persons responsible for communication is to provide information to stakeholders in order to obtain or strengthen support for their actions. In an informational approach to communication, the opinions of stakeholders do not influence changes in the organization.

Similarly, in the case of the second communication strategy-the asymmetric communication strategy-here, the stakeholders do not influence the organization's strategic activities. Although in this kind of communication, the information flow is in both directions, it is asymmetrical. The organization tries to influence the behavior of its stakeholders through its communications. Communication from the stakeholders is seen as feedback when the organization wants to find out whether it has support for activities in its environment. The communication's asymmetry and asymmetry of the organization's relationship with its stakeholders are also visible in the place the organization designates its stakeholders in this process. The environment is perceived as influencing the organization's decisions; however, only messages that passively respond to the initiatives taken by the organization are taken into account.

Only the third type of strategy presented by the researchers-the strategy of stakeholder engagement-assumes a dialogue between the organization and its environment. Each of the broadcasters tries to convince the other party to changes in some areas. Thanks to regular communication, both the organization can influence the behavior of stakeholders and their attitudes towards it, as well as the stakeholders themselves, have the opportunity to express their opinions and draw the organization's attention to emerging problems related to its activities. For an organization conducting constant dialogue with the environment creates a chance to collect current information concerning stakeholders' expectations and the level of influence, which particular groups of stakeholders can exert on its activity. Therefore, the main task of persons responsible for communicating CSR in an organization is to ensure permanent and systematic dialogue with the environment, involving all main groups of stakeholders [15].

Based on the typology proposed by Morsing and Schultz [29], Colleoni [28], while researching social media, identified two main strategies of CSR communication used by organizations:

1. internal (self-centered),

2. dialogue.

The internal strategy assumes that the organization, in the model of internal consultations, establishes a plan of socially responsible activities. In contrast, by implementing the dialogue strategy, the organization actively involves its stakeholders in the arrangements concerning the CSR policy and activities. Table 2 presents the typologies of the social responsibility communication strategy.

The analysis of CSR communication strategies by organizations may raise the question about the possibility of drawing general conclusions about particular phenomena because there is a doubt whether strategies may differ depending on the target group they were prepared for [45]. The research conducted [45] showed that organizations do not differ significantly in the assessment of the importance of particular stakeholder groups, divided into primary and secondary ones. It means that their strategies for stakeholder relations are based on fundamental systemic aspects related to the communication process and can be analyzed based on quantitative research [15]. 
Table 2. Typologies of social responsibility communication strategies.

\begin{tabular}{ccc}
\hline Author & $\begin{array}{c}\text { Type of Social Responsibility } \\
\text { Communication Strategy }\end{array}$ & Differentiator \\
\hline Wagner (2009) & $\begin{array}{c}\text { Proactive } \\
\text { Reactive }\end{array}$ & $\begin{array}{c}\text { Posts' frequency, financial expenditure on } \\
\text { CSR communication }\end{array}$ \\
\hline Drumwright (1996) & $\begin{array}{c}\text { Economic } \\
\text { Non-economic } \\
\text { Mixed }\end{array}$ & Objective and content of a communication \\
\hline Kim at al. (2014) & $\begin{array}{c}\text { Corporate ability } \\
\text { Corporate social responsibility } \\
\text { Horsing and Schultz (2006) }\end{array}$ & Objective and content of a communication \\
& $\begin{array}{c}\text { Asymmetric communication } \\
\text { Stakeholder engagement }\end{array}$ & Stakeholders engagement \\
\hline Colleoni (2013) & Internal & Stakeholders engagement \\
\hline
\end{tabular}

Source: own study based on Wagner [42]; Drumwright [43]; Kim et al. [36]; Morsing and Schultz [29]; Colleoni [28].

\section{Methodology}

The rationale for undertaking the pilot studies was the small number of research works devoted to communicating the Sustainable Development Goals in social media. The four largest ICT companies, The Big ICT Four, were selected for the study-Amazon, Apple, Google, Facebook. These companies, as leading ICT companies, have a significant impact on both the global economy and the daily lives of individuals. The Big ICT Four's impact on the environment is also significant, including through the production of new product models, the volume of data transmission, the cost of maintaining a server room or disposing of used equipment. The involvement of ICT companies in communicating the activities undertaken for Sustainable Development and promoting the SDGs to stakeholders is one of the many opportunities to get involved in the implementation of the Agenda 2030 that emerges for the most significant ICT organizations.

Taking the above into account, it seems crucial to research the communication of Sustainable Development and promotion of the SDGs by ICT companies.

An analysis of the literature shows that the research conducted so far on Sustainable Development communication and activities undertaken by enterprises in this field has focused on the analysis of information contained in companies' websites or non-financial reports [46]. Non-financial reporting arouses great interest among researchers of Sustainable Development and corporate responsibility communication, among other things, due to the significant amount of information that is available online and does not require the company's consent to access it while ensuring source reliability [46]. The disadvantage of reports as a communication tool, as well as websites, is the unilateral nature of communication. Companies through reports and company websites can inform about actions taken in the implementation of the SDGs. They can also promote the idea of Sustainable Development and the goals. Such tools, however, make it impossible for the public to get involved in the discussion about Sustainable Development and the actions taken by companies. Communication through non-financial reports and websites only serves as an advocacy function to inform the public and raise their awareness of the SDGs. Companies, as business organizations working with many stakeholder groups, should implement communication for development in the form of a two-way communication process involving sender and recipient and enabling the exchange of opinions and experiences. Such tasks can be carried out by companies using social media in the communication process to make the sender's and recipient's response possible in real-time. Communicating with social media can reach a wide range of recipients; therefore, the research on Sustainable Development communication of selected ICT 
companies was conducted by the authors using established companies' Facebook and Twitter accounts. The research was conducted to find answers to the following research questions:

Q1: Do the surveyed companies communicate about the SDGs?

Q2: Do the surveyed companies use social media to communicate about the SDGs?

Q3: What types of strategies did the companies adopt in communicating through social media?

In order to answer the research questions and identify the social media communication strategy implemented by the surveyed companies, a text corpus consisting of 1400 entries (posts and tweets) on the official company Facebook and Twitter accounts was collected for analysis. The corpus was created based on the entries posted in the accounts in the period from 1 January to 31 December 2019. Then the content of the collected entries was analyzed according to the coding procedure adopted by authors. From the text corpus, entries concerning sustainable development and the SDGs were separated. When analyzing the content of the entries, coding tags were indicated, which define the thematic areas related to particular SDGs. The entries have been grouped according to the separated SDGs. The list of subject areas and coding tags is presented in Table 3. Each company can carry out SGDs-related activities in different areas and various topics related to SGDs also can be communicated through social media. Table 3 describes those areas of the SDGs in which the company took action in 2019 and about which it communicated through social media.

Table 3. Subjects of entries concerning Sustainable Development Goals (SDGs) in the surveyed companies' social media.

\begin{tabular}{|c|c|}
\hline Company & SDGs in Social Media Entries \\
\hline Amazon & $\begin{array}{c}1 \text { No poverty } \\
3 \text { Good health and well-being } \\
4 \text { Quality education } \\
11 \text { Sustainable cities and communities } \\
15 \text { Life on land } \\
16 \text { Peace, justice and strong institutions } \\
17 \text { Partnerships for the Goals }\end{array}$ \\
\hline Facebook & $\begin{array}{c}3 \text { Good health and well-being } \\
4 \text { Quality education } \\
5 \text { Gender equality } \\
10 \text { Reduced inequalities } \\
16 \text { Peace, justice and strong institutions }\end{array}$ \\
\hline Google & $\begin{array}{c}1 \text { No poverty } \\
2 \text { Zero hunger } \\
3 \text { Good health and well-being } \\
4 \text { Quality education } \\
5 \text { Gender equality } \\
7 \text { Affordable and clean energy } \\
10 \text { Reduced inequalities } \\
13 \text { Climate action } \\
15 \text { Life on land } \\
16 \text { Peace, justice and strong institutions } \\
17 \text { Partnerships for the Goals }\end{array}$ \\
\hline
\end{tabular}

The theoretical basis of the research process was the typology of social media communication adopted by Kim and Rader [47], distinguishing three types of strategies-Corporate Ability strategy (CA), Corporate Social Responsibility strategy (CSR) and hybrid strategy. The Corporate Ability strategy is characterize by the fact that the number of posts on products and services offered by the company outweighs the number of posts on topics related to corporate responsibility and involvement in Sustainable Development. When we have opposite situation we talk about Corporate Social responsibility strategy. The hybrid strategy combines both approaches to communication. 
Based on the collected quantitative data (total number of entries and the number of entries concerning Sustainable Development and SDGs), the type of social media communication strategy implemented by companies was defined.

\section{Results and Discussion}

The analysis of the content of 1400 posts posted on company social media accounts on Twitter and Facebook showed that the surveyed companies prefer the Corporate Ability communication strategy. The number of posts on products and services offered by the company outweighs the number of posts on topics related to corporate responsibility and involvement in Sustainable Development. For Google, Facebook and Amazon, the percentage of posts on topics and activities related to Sustainable Development was between $7 \%$ and $17 \%$ of the total number of posts made by the companies in the period from 1 January to 31 December 2019 (Table 4).

Table 4. Results of social media messages' analysis.

\begin{tabular}{|c|c|c|c|}
\hline Company & Communication Tool & The Total Number of Posts & $\begin{array}{l}\text { The Percentage of Posts Related } \\
\text { to Sustainable Development }\end{array}$ \\
\hline \multirow{2}{*}{ Amazon } & Twitter & 212 & 13 \\
\hline & Facebook & 152 & 11 \\
\hline \multirow[b]{2}{*}{ Facebook } & Twitter @Facebook & 168 & 60 \\
\hline & $\begin{array}{c}\text { Newsroom } \\
\text { Facebook }\end{array}$ & 47 & 17 \\
\hline \multirow{2}{*}{ Google } & Twitter & 660 & 13 \\
\hline & Facebook & 174 & 7 \\
\hline
\end{tabular}

Apple did not communicate with stakeholders on Sustainable Development-related topics through official social media accounts (Facebook and Twitter); there was no record of such communication during the audited period. Facebook, on its official company account Twitter also did not carry out communication activities in 2019 but reported on the activities undertaken in the context of corporate responsibility and Sustainable Development through the company newsroom account (@Facebook Newsroom). In this case, the $60 \%$ percentage leads to the conclusion that the company is adopting a hybrid strategy (concerning recipients of the @Facebook Newsroom account on Twitter). In contrast, the company's Facebook account is operated according to the CA strategy, where the number of entries concerning the products and services offered by the company prevails.

In 2010, Kim and Rader [47] analyzed the content of Fortune 100 companies' websites. The results of the analysis showed that the highest-ranked companies implemented the CSR communication strategy. At the same time, the organizations placed on the last positions of the list preferred the Corporate Ability communication strategy. In a study of communication strategy conducted four years later [35] on the official Facebook accounts of Fortune 100 companies, it was shown that $89 \%$ of the companies applied the Corporate Ability strategy and only $9 \%$ of the studied cases were implemented CSR communication strategy. The remaining enterprises applied a hybrid strategy using the above mentioned two strategies in the same dimension. It can be concluded that enterprises put more emphasis on communicating their pro-environmental and pro-social activities through websites than through social media. At the same time, social media are a tool for creating the image of the organization as an expert in the industry and market leader.

Similar conclusions are drawn from the analysis of the content of the Big ICT Four's websites and the reports, where organizations provide extensive information on their social and environmental activities and participation in partnerships for sustainable development (e.g., Google's partnership with The UN Environment Programme or Facebook's participation in the Global Partnership for Sustainable Development Data). However, this information does not appear in the social media used 
by companies. None of the entries analyzed for twelve months have included the concept of the Sustainable Development Goals.

The results of the research show that enterprises prefer CSR strategy in communication through unilateral communication tools, such as websites and non-financial reports. In communicating through social media, that is, two-way communication tools enabling the exchange of opinions and experiences, the surveyed enterprises apply the Corporate Ability strategy and the majority of the messages posted are aimed at promoting products and services.

\section{Conclusions}

Research on non-financial communication strategies of enterprises has been conducted in recent years, mainly in the area of corporate social responsibility and sustainable development understood in an environmental context. Communication about the SDGs has not been the subject of research, probably due to the short period that has passed since the objectives were officially announced (2015). A small amount of literature related to the topic of SDGs communication was a limitation in conducting literature research.

The article discusses the subject of communicating the SDGs on the example of social media analysis of the four most significant companies in the ICT industry. The results of the research show that although companies engage in activities for the implementation of the Sustainable Development Goals and report on their activities on company websites and in non-financial reports, they do not use social media to communicate about Sustainable Development and SDGs. It seems reasonable to expect companies with such a wide range of impact as The Big ICT Four to promote the idea of Sustainable Development and actions taken to achieve the goals with the use of tools with the highest possible impact, such as social media.

On account of the above-mentioned results, it can be concluded that future research should concern the identification of barriers, which cause that ICT companies do not communicate directly about joining the implementation of the SDGs and do not adopt a CSR strategy in communicating with stakeholders in social media. It is also worthwhile to conduct research on communication about SDGs in other industries in the future [48,49].

The conducted research was only a pilot study and the subjects of the study were the four largest enterprises, which does not give grounds to extend the conclusions to the whole population of the ICT industry. As the ICT industry is one of the fastest-growing industries in the global economy and has a significant impact on society and the environment, it is worthwhile to broaden future research to include more enterprises so that the statistical surveys allow for a generalization of conclusions. The answer to this question may serve as a basis for another research issue, which will be to define the determinants of communication about the SDGs and key factors influencing the effectiveness of the adopted communication strategy.

Funding: This research received no external funding.

Acknowledgments: Author want to extend a gratitude towards the editor and reviewers for their valuable suggestions and feedback for the improvement in the quality of the paper considerably.

Conflicts of Interest: Author declare no conflict of interest.

\section{References}

1. The Agenda for Sustainable Development 2030. Available online: https://sustainabledevelopment.un.org/po st2015/transformingourworld (accessed on 3 February 2020).

2. Sustainable Development Goals. Available online: https://ungc.org.pl/sdg/sustainable-develompent-goals (accessed on 3 February 2020).

3. The Responsible Business Trends Report 2018 by Ethical Corporation. Available online: http://odpowiedzial nybiznes.pl/wp-content/uploads/2019/07/Responsible_Business_Trends_2018_Report_2.pdf (accessed on 2 February 2020). 
4. Olszewska, K. The information and communication technologies (ICT) sector in improving the international competitiveness of the economy, following the example of China (Sektor technologii informacyjnych i komunikacyjnych (ICT) w podnoszeniu międzynarodowej konkurencyjności gospodarki na przykładzie Chin). In Economy: Innovations and Development (Gospodarka: Innowacje i rozwój); Electronic Document; Winiarski, M., Ed.; Wydawnictwo Uniwersytetu Wrocławskiego: Wroclaw, Poland, 2011; pp. 85-101.

5. Martinuzzi, A.; Kudlak, R.; Faber, C.; Wiman, A. CSR Activities and Impacts of the ICT Sector. RIMAS Work. Pap. 2011, 5, 7-13.

6. Fraser, G. Smartphones are destroying our environment. Available online: https://mediaphilia.pl/2018/12/s martfony-niszcza-nasze-srodowisko/ (accessed on 10 February 2020).

7. Green IT Network Europe Project. Available online: https://ec.europa.eu/regional_policy/en/projects/denma rk/green-it-network-europe-making-ict-sustainable (accessed on 10 February 2020).

8. Warnock, K.; Schoemaker, E.; Wilson, M. The Case for Communication in Sustainable Development; Panos London: London, UK, 2007; pp. 6-9, 50-54. Available online: http://panoslondon.panosnetwork.org/wp-content/files /2007/09/The-Case-for-Communication-in-Sustainable-Development.pdf (accessed on 2 February 2020).

9. Zuzek, D.K. Corporate social responsibility and sustainable business development (Społeczna odpowiedzialność biznesu a zrównoważony rozwój przedsiębiorstw). Sci. J. Małopolska Wyższa Szkoła Ekon. w Tarn. (Zesz. Nauk. Małopolskiej Wyższej Szkoły Ekon. w Tarn.) 2012, 2/21, 197-207.

10. Sustainable Development. Available online: Unic.un.org.pl (accessed on 2 February 2020).

11. Dahlsrud, A. How corporate social responsibility is defined: An analysis of 37 definitions. Corp. Soc. Responsib. Environ. Manag. 2008, 15, 1-13. [CrossRef]

12. Corporate Social Responsibility. Available online: https://www.iso.org/iso-26000-social-responsibility.html (accessed on 10 February 2020).

13. Laszlo, C. The Sustainable Company (Firma zrównoważonego rozwoju), 1st ed.; Studio Emka: Varsaw, Poland, 2008.

14. Maignan, I.; Ralston, D.A. Corporate Social Responsibility in Europe and the U.S.: Insights from businesses' self-presentation. J. Int. Bus. Stud. 2001, 33, 497-514. [CrossRef]

15. Losa-Jonczyk, A. Efectiveness of social media communication of energy, fuel and mining companies' corporate social responsibility. Ph.D. Thesis, University of Economics in Katowice, Katowice, Poland, 27 September 2019.

16. Golob, U.; Verk, N.; Ellerup-Nielsen, A.; Thomsen, C.; Elving, W.L.J.; Podnar, K. The communicative stance of CSR: Reflections of the value of CSR communication. Corp. Commun. An Int. J. 2017, 22, 166-177. [CrossRef]

17. Freeman, R.E.; McVea, J. A Stakeholder Approach to Strategic Management. Darden Bus. Sch. Work. Pap. 2001, 1-2, 1-32. [CrossRef]

18. Formbrun, C.; Shanley, M. What is in name? Reputation Building and Corporate Strategy. Acad. Manag. J. 1990, 33, 233-258.

19. Crane, A.; Glozer, S. Researching Corporate Social Responsibility Communication: Themes, Opportunities and Challenges. J. Manag. Stud. 2016, 53, 1223-1252. [CrossRef]

20. Report Shell. Available online: https://www.shell.pl/zrownowazony-rozwoj/raporty.html (accessed on 10 February 2020).

21. The European Communication Monitor 2011/2014. Available online: http://www.communicationmonitor.eu (accessed on 20 January 2020).

22. Mefalopulos, P.; Grenna, L. Promoting sustainable development through strategic communication. In Communicating Protected Areas, 1st ed.; Hamu, D., Auchincloss, E., Goldstein, W., Eds.; Commission on Education and Communication, IUCM: Gland, Switzerland; Cambridge, UK, 2004; pp. 24-30.

23. He, H.W.; Balmer, J.M.T. Identity studies: Multiple perspectives and implications for corporate-level marketing. Eur. J. Mark. 2007, 41, 765-785. [CrossRef]

24. Etter, M.; Plotkowiak, T.; Stanoevska-Slabeva, K. CSR Communication Strategies for Twitter: Microblogging as a Tool for Public Relations. In Proceedings of the 61st Annual Meeting of the International Communication Association, TBA, Boston, MA, USA, 28 May 2011.

25. Lee, K.; Oh, W.Y.; Kim, N. Social media for socially responsible firms: Analysis of Fortune 500's Twitter profiles and their CSR/CSIR ratings. J. Bus. Ethics 2013, 18, 791-806. [CrossRef]

26. Tao, W.; Wilson, C. Fortune 1000 communication strategies on Facebook and Twitter. J. Commun. Manag. 2015, 19, 208-223. [CrossRef]

27. Etter, M. Broadcasting, reacting, engaging —Three strategies for CSR communication in Twitter. J. Commun. Manag. 2014, 18, 662-674. [CrossRef] 
28. Colleoni, E. CSR communication strategies for organizational legitimacy in social media. Corp. Commun. Int. J. 2013, 18, 228-248. [CrossRef]

29. Morsing, M.; Schultz, M. Corporate social responsibility communication: Stakeholder information, response and involvement strategies. Bus. Ethics Eur. Rev. 2006, 15, 323-338. [CrossRef]

30. Lopez, M.; Sicila, M.; Moyeda-Carabaza, A.A. Creating identification with brand communities on Twitter: The balance between need for affiliation and need for uniqueness. Internet Res. 2017, 27, 21-51. [CrossRef]

31. Sundstrom, B.; Levenshus, A.B. The art of engagement: Dialogic strategies on Twitter. J. Commun. Manag. 2017, 21, 17-33. [CrossRef]

32. Araujo, T.; Kollat, J. Communicating effectively about CSR on Twitter: The power of engaging strategies and storytelling elements. Internet Res. 2018, 28, 419-431. [CrossRef]

33. Farache, F.; Tetchner, I.; Kollat, J. CSR Communication on Twitter: An Exploration into Stakeholder reactions. In Corporate Responsibility and Digital Communities, 1st ed.; Grigore, G., Stancu, A., McQueen, D., Eds.; Palgrave Macmillian: Cham, Switzerland, 2018; pp. 145-163.

34. Shin, W.; Pang, A.; Kim, H.J. Building relationships through integrated online media: Global organizations' use of brand web sites, Facebook and Twitter. J. Bus. Tech. Commun. 2015, 29, 184-220. [CrossRef]

35. Wigley, S.; Lewis, B.K. Rules of engagement: Practice what you tweet. Public Relat. Rev. 2012, 38, $165-167$. [CrossRef]

36. Kim, S.; Kim, S.Y.; Sung, K. Fortune 100 companies' Facebook strategies: Corporate ability versus social responsibility. J. Commun. Manag. 2014, 18, 343-362. [CrossRef]

37. Haigh, M.; Brubaker, P.; Whiteside, E. Facebook: Examining the information presented and its impact on stakeholders. Corp. Commun. Int. J. 2013, 18, 52-69. [CrossRef]

38. Cho, M.; Furey, L.D.; Mohr, T. Communicating Corporate Social Responsibility on Social Media: Strategies, Stakeholders, and Public Engagement on Corporate Facebook. Bus. Prof. Commun. Q. 2016, 80, 52-69. [CrossRef]

39. Abitbol, A.; Lee, S.Y. Messages on CSR-dedicated Facebook pages: What works and what doesn't. Public Relat. Rev. 2017, 43, 796-808. [CrossRef]

40. Wróbel, M. Planning communication activities (Planowanie działań komunikacyjnych). In The Art of Public Relations. from the Experience of Polish Practitioners (Sztuka public relations. Z doświadczeń polskich praktyków), 1st ed.; Janiszewska, B., Ed.; Związek Firm Public Relations: Varsaw, Poland, 2004; pp. 7-26.

41. Stanaland, A.J.S.; Lwin, M.O.; Murphy, P.E. Consumer perceptions of the antecedents and consequences of corporate social responsibility. J. Bus. Ethics 2011, 102, 47-55. [CrossRef]

42. Wagner, T.; Lutz, R.; Weitz, B.A. Corporate Hypocrisy: Overcoming the Threat of Inconsistent Corporate Social Responsibility Perceptions. J. Mark. 2009, 73, 77-91. [CrossRef]

43. Drumwright, M.E. Company advertising with a social dimension: The role of noneconomic criteria. J. Mark. 1996, 60, 71-87. [CrossRef]

44. Bhattacharya, C.B.; Sen, S. Doing better at doing good: When, why, and how consumers respond to corporate social initiatives. Calif. Manag. Rev. 2004, 47, 9-24. [CrossRef]

45. Fryzeł, B. Stakeholder relations strategies: Practical aspect of CSR on the example of Polish enterprises (Strategie relacji z interesariuszami: Praktyczny aspekt CSR na przykładzie polskich przedsiębiorstw). Sci. J. Ostrołeka Sci. Soc. 2011, 25, 297-311.

46. Jones, P.; Wynn, M.; Hillier, D.; Comfort, D. The Sustainable Development Goals and Information and Communication Technologies. Indones. J. Sustain. Account. Manag. 2017, 1, 1-15. [CrossRef]

47. Kim, S.; Rader, S. What they can do versus how much they care: Assessing corporate communication strategies on Fortune 500 web sites. J. Commun. Manag. 2010, 14, 59-80. [CrossRef]

48. Monteiro, N.B.R.; A parecida da Silva, E.; Neto, J.M.M. Sustainable development goals in mining. J. Clean. Prod. 2019, 228, 509-520. [CrossRef]

49. Santika, W.G.; Anisuzzaman, M.; Bahri, P.A.; Shafiullah, G.M.; Rupf, G.V.; Urmee, T. From goals to joules: A quantitative approach of interlinks between energy and the Sustainable Developments Goals. Energy Res. Soc. Sci. 2019, 50, 201-214. [CrossRef]

(C) 2020 by the author. Licensee MDPI, Basel, Switzerland. This article is an open access article distributed under the terms and conditions of the Creative Commons Attribution (CC BY) license (http://creativecommons.org/licenses/by/4.0/). 